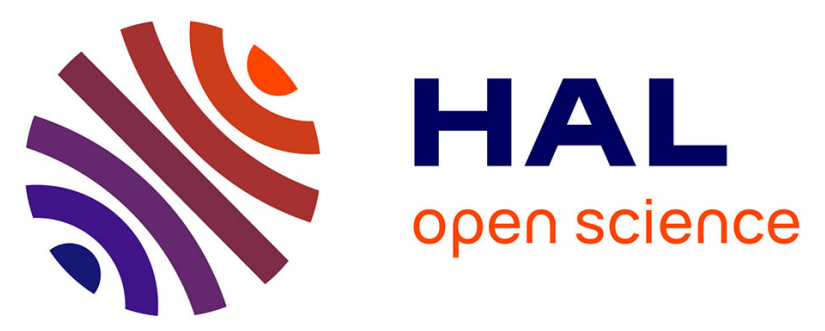

\title{
Tetraploid Citrumelo 4475 (Citrus paradisi L. Macf. x Poncirus trifoliata L. Raf.) Rootstocks Improve Common Clementine Tolerance to Long-term Nutrient Deficiency (Citrus clementina Hort. ex Tan)
}

Julie Oustric, Stéphane Herbette, Yann Quilichini, Raphaël Morillon, Jean Giannettini, Liliane Berti, Jérémie Santini

\section{To cite this version:}

Julie Oustric, Stéphane Herbette, Yann Quilichini, Raphaël Morillon, Jean Giannettini, et al.. Tetraploid Citrumelo 4475 (Citrus paradisi L. Macf. x Poncirus trifoliata L. Raf.) Rootstocks Improve Common Clementine Tolerance to Long-term Nutrient Deficiency (Citrus clementina Hort. ex Tan). 2021. hal-03102354

\author{
HAL Id: hal-03102354 \\ https://hal.inrae.fr/hal-03102354
}

Preprint submitted on 7 Jan 2021

HAL is a multi-disciplinary open access archive for the deposit and dissemination of scientific research documents, whether they are published or not. The documents may come from teaching and research institutions in France or abroad, or from public or private research centers.
L'archive ouverte pluridisciplinaire HAL, est destinée au dépôt et à la diffusion de documents scientifiques de niveau recherche, publiés ou non, émanant des établissements d'enseignement et de recherche français ou étrangers, des laboratoires publics ou privés. 


\section{Tetraploid Citrumelo 4475 (Citrus paradisi L. Macf. x Poncirus trifoliata L. Raf.) Rootstocks Improve Common Clementine Tolerance to Long-term Nutrient Deficiency (Citrus clementina Hort. ex Tan)}

Julie Oustric ( $D$ oustric_j@univ-corse.fr)

CNRS, UMR 6134 SPE, Université de Corse

\section{Stéphane Herbette}

UCA, INRA, PIAF, Clermont-Ferrand, France

Yann Quilichini

CNRS, UMR 6134 SPE, Université de Corse

Raphaël Morillon

UMR AGAP, Département BIOS, CIRAD, Station de Roujol

Jean Giannettini

CNRS, UMR 6134 SPE, Université de Corse

Liliane Berti

CNRS, UMR 6134 SPE, Université de Corse

Jérémie Santini

CNRS, UMR 6134 SPE, Université de Corse

\section{Research Article}

Keywords: Nutrient deficiency, nutritious food, Citrus crops, genotype

DOI: https://doi.org/10.21203/rs.3.rs-116997/v1

License: (c) (i) This work is licensed under a Creative Commons Attribution 4.0 International License.

Read Full License 


\section{Abstract}

Nutrient deficiency alters growth and the production of high-quality nutritious food. In Citrus crops, rootstock technologies have become a key tool for enhancing tolerance to abiotic stress. The use of doubled diploid rootstocks can improve adaptation to lower nutrient inputs. This study investigated leaf structure and ultrastructure and physiological and biochemical parameters of common clementine scions (C) grafted on diploid (2x) and doubled diploid (4x) Carrizo citrange (C/CC2x and C/CC4x) and Citrumelo 4475 (C/CM2x and C/CM4x) rootstocks under optimal fertigation and after seven months of nutrient deficiency. Rootstock ploidy level had no impact on structure but induced changes in the number and/or size of cells and some cell components of common clementine leaves under optimal nutrition. Rootstock ploidy level did not modify gas exchanges in Carrizo citrange but induced a reduction in the leaf net photosynthetic rate in Citrumelo 4475. By assessing foliar damage, changes in photosynthetic processes and malondialdehyde accumulation, we found that $\mathrm{C} / \mathrm{CM} 4 \mathrm{x}$ were less affected by nutrient deficiency than the other scion/rootstock combinations. Their greater tolerance to nutrient deficiency was probably due to the better performance of the enzyme-based antioxidant system. Nutrient deficiency had similar impacts on $\mathrm{C} / \mathrm{CC} 2 \mathrm{x}$ and $\mathrm{C} / \mathrm{CC} 4 \mathrm{x}$. Tolerance to nutrient deficiency can therefore be improved by rootstock polyploidy but remains dependent on the rootstock genotype.

\section{Introduction}

Fruit crops, especially citrus fruits, require large amounts of fertilizers to ensure good production and fruit quality. Today, the challenge for sustainable agriculture, and particularly organic agriculture, is to reduce the use of inputs in crops. Reducing inputs optimizes the economic outcome while limiting the environmental impact.

Water and minerals absorbed by roots in the soil are essential for plant development, growth and reproduction. Fourteen minerals are considered essential and these can be divided into two groups: the macroelements ( $\mathrm{N}, \mathrm{K}, \mathrm{P}, \mathrm{Ca}, \mathrm{Mg}$ and $\mathrm{S}$ ) which are constituents of organic matter (proteins, nucleic acids) or play a strong osmotic role, and microelements ( $\mathrm{Zn}, \mathrm{Cu}, \mathrm{Fe}, \mathrm{Mn}, \mathrm{B}, \mathrm{Mo}, \mathrm{Cl}$ and $\mathrm{Ni}$ ), which are only involved as specific cofactors or constituents of certain enzymes ${ }^{1-3}$. Mineral-deficient plants present various visual symptoms, such as necrosis, chlorosis, dark green foliage, or stunted growth ${ }^{4}$. Essential mineral deficiency alters plant primary metabolism and this disrupts the physiological and biochemical processes leading to changes in leaf structure and ultrastructure ${ }^{5,6}$. Moreover, cells must cope with an overproduction of reactive oxygen species (ROS) such as singlet oxygen $\left(\mathrm{O}^{*}\right)$, hydroxyl radicals $\left(\mathrm{OH}^{*}\right)$, superoxide anion $\left(\mathrm{O}_{2}{ }^{--}\right)$and hydrogen peroxide $\left(\mathrm{H}_{2} \mathrm{O}_{2}\right)$ which cause membrane leakage due to lipid peroxidation and damage to proteins and nucleic acids ${ }^{7-9}$. As a result, ROS defence mechanisms are activated by a set of antioxidant compounds (metabolites such as ascorbate and proline) and antioxidant enzymes (superoxide dismutase (SOD), catalase (CAT), ascorbate peroxidase (APX) and dehydroascorbate reductase (DHAR)). Adapted genotypes are therefore sought in order to propose cultural itineraries more suitable to low input conditions. 
In citrus crops, improving the performance of varieties is based on the scion/rootstock combination forming the aerial parts and roots of the plant, respectively. The impact of the rootstock on the scion lies in its influence on flowering, fruit quality, canopy size, and resistance, among other parameters ${ }^{10}$. Good relations between rootstock and scion are essential for the efficient translocation of water and mineral nutrients and to promote biomass production and tolerance to biotic and abiotic factors, such as nutrient deficiency ${ }^{11,12}$. Improved root system vigour in citrus rootstocks results in increased soil nutrient and water uptake ${ }^{13,14}$. All modern cultivated varieties of citrus are now grafted on diploid rootstocks and therefore have two sets of chromosomes in their genetic heritage. However, incomplete mitosis of somatic embryos may occur in seedlings of diploid (2x) apomictic genotypes with formation of doubled diploid (4x) genotypes ${ }^{15}$.

Recent advances have shown that rootstock tetraploidy can improve the tolerance of a scion. Grafting of Valencia Delta sweet orange (Citrus sinensis L.) on $4 \mathrm{x}$ rangpur lime (Citrus limonia) rootstock was found to improve its tolerance to water stress by changing patterns of gene expression in Rangpur lime citrus roots regulating adaptation to water deficit ${ }^{16}$. Natural chilling stress tolerance associated with a robust antioxidant system was also enhanced in common clementine (Citrus clementina Hort. ex Tan) grafted with Carrizo citrange (Citrus sinensis Osb.x Poncirus trifoliata L. Raf.) $4 \times$ rootstock $^{17}$. Chromium tolerance of Kinnow mandarin (Citrus nobilis Lour x Citrus deliciosa Ten) grafted on three $4 \mathrm{x}$ rootstocks (Poncirus trifoliata [L.], Citrus reshni, and Citrus limonia Osbeck.) may be attributed to chromium sequestration in roots with lower transfer to leaves in $4 x$ rootstocks ${ }^{18}$. The use of rootstocks better adapted to environmental constraints seems to be a promising eco-friendly strategy.

Many Citrus genotypes are used as rootstock for citrus cultivation. Genotypes belong either to the Citrus genus such as Volkamer lemon or are obtained by hybridization between Citrus and Poncirus genus progenitors such as Citrumelo 4475 and Carrizo citrange. Volkamer lemon which is used as rootstock for lemon, is adapted to dry, calcareous and saline soils and presents tolerance to Tristeza, cachexia and exocortis. Citrumelo 4475 imparts cold tolerance to the scion. Citrange Carrizo is frequently used in acidic and neutral soils but not in dry areas because of its limited performance under drought conditions. These two genotypes inherited Tristeza tolerance from their Trifoliate orange progenitor and give clementine varieties that produce a high yield and fruit quality ${ }^{19}$.

In a previous study, we compared leaf structure and ultrastructure under nutrient deficiency of two genotypes used worldwide as rootstock for citrus cultivation, the Citrumelo 4475 (Citrus paradisi L. Macf. $\times$ Poncirus trifoliata L. Raf.) and Volkamer lemon (Citrus limonia Osb.) with both 2x and 4x genotypes ${ }^{20}$. Results showed an increase in tolerance to nutrient deficiency in $4 x$ genotypes. Doubled diploid genotypes presented less degradation of ultrastructural components such as chloroplasts, thylakoids, mitochondria and starch grains associated with a smaller decrease in leaf net photosynthetic rate $\left(P_{\text {net }}\right)$, stomatal conductance $\left(g_{\mathrm{s}}\right)$ and chlorophyll fluorescence $\left(F_{\mathrm{v}} / F_{\mathrm{m}}\right)$ compared to $2 \mathrm{x}$ genotypes. 
The higher tolerance to nutrient deficiency was linked to the reduced accumulation of malondialdehyde (MDA) and $\mathrm{H}_{2} \mathrm{O}_{2}$ in Citrumelo $44754 x$ than in the $2 x$, implying a more efficient antioxidant system in the $4 x$ genotype. However, few differences in the antioxidant system and oxidative status were observed between $2 x$ and $4 x$ Volkamer lemons.

The aim of this study was therefore to determine the impact of rootstock ploidy level on the $2 x$ common clementine scion during nutrient deficiency. We selected common clementine grafted on two rootstocks used worldwide for clementine cultivation, i.e. Citrumelo 4475 (C/CM2x) and Carrizo citrange (C/CC2x) in both $2 x$ and $4 x$ types (C/CM4x and C/CC4x, respectively). The effect of rootstock ploidy level on common clementine scions under nutrient deficiency was investigated by studying common clementine leaf structure and ultrastructure and physiological and biochemical parameters.

\section{Results And Discussion}

\section{Effect of rootstock ploidy level on anatomical properties of common clementines under control conditions}

Whatever the rootstock genotype and ploidy level, microscopic examination of leaf surface imprints confirmed the presence of stomata only on their abaxial surface that were surrounded by ordinary epidermal cells ${ }^{29}$ (anomocytic organization) (Fig. 1). Rootstock tetraploidy did not induce any changes in the location of stomata or the epidermal cell structure of common clementine leaves. This agrees with this anomocytic organization observed on leaves of tetraploid seedlings ${ }^{20}$.

Stomata size was unchanged in $\mathrm{C} / \mathrm{CM} 4 \mathrm{x}$ and $\mathrm{C} / \mathrm{CC} 4 \mathrm{x}$ combinations. Conversely, stomata density decreased and ostiole sizes increased in $\mathrm{C} / \mathrm{CC} 4 \mathrm{x}$ compared to $\mathrm{C} / \mathrm{CC} 2 \mathrm{x}$ combinations (Table 1). Studies have shown a positive correlation between stomata and ostiole size and a negative correlation between stomata density and ploidy level in both $4 x$ ungrafted genotypes and $3 x$ clementine in comparison to their $2 x$ counterparts $20,29,30$. Our study showed that $4 x$ rootstocks had no effect on stomata sizes in $2 x$ common clementine scions and a non-systematic impact on ostiole size and stomatal density, putatively through changes in hydraulics or mineral inputs. The decrease in stomatal density caused by rootstock tetraploidy in the $\mathrm{C} / \mathrm{CC} 4 \mathrm{x}$ combination was not associated with any changes in gas exchanges compared to its $\mathrm{C} / \mathrm{CC} 2 \mathrm{x}$ counterpart (Table 1 ; Fig. 1 and 5). The increase in ostiole size in the $\mathrm{C} / \mathrm{CC} 4 \mathrm{x}$ combination compared to its $\mathrm{C} / \mathrm{CC} 2 \mathrm{x}$ counterpart suggests an adjustment of the stomata opening to compensate for the reduced stomatal density and maintain stomatal conductance ${ }^{31}$. This adjustment could be due to the considerable degradation of starch grains in the guard cells in the first hour of light contributing to a rapid increase in the opening of the stomata in parallel with the activation of membrane ion transport ${ }^{32,33}$.

Despite identical physical stomatal attributes between $\mathrm{C} / \mathrm{CM} 2 \mathrm{x}$ and $\mathrm{C} / \mathrm{CM} 4 \mathrm{x}$ combinations, analysis of the gas exchange parameters revealed a decrease of $P_{\text {net }}$ in the C/CM4x combination (Table 1; Fig. 1 and 
5). Other factors than leaf structure therefore appear to be involved in the regulation of photosynthesis in the $\mathrm{C} / \mathrm{CM} 4 \mathrm{x}$ combination.

At ultrastructural level, rootstock tetraploidy initiated changes in the number and size of the main cell components of the $2 x$ common clementine leaves (Tables 2 and 3). Cell size and thickness in both palisade and spongy mesophylls were reduced in $\mathrm{C} / \mathrm{CC} 4 \mathrm{x}$ compared to $\mathrm{C} / \mathrm{CC} 2 \mathrm{x}$, whereas they increased in C/CM4x compared to C/CM2x (Tables 2 and 3; Fig. 2 and 3). These ultrastructural modifications were the only identical changes in $\mathrm{C} / \mathrm{CM} 4 \mathrm{x}$ and the ungrafted rootstock counterpart ${ }^{20}$. In contrast to its ungrafted counterpart, $\mathrm{C} / \mathrm{CM} 4 \mathrm{x}$ showed a lower $P_{\text {net }}$ and similar chloroplast numbers to $\mathrm{C} / \mathrm{CM} 2 \mathrm{x}^{20}$ (Tables 2 and 3; Fig. 2, 3 and 5A). Chloroplast enlargement in palisade mesophyll brought about by rootstock tetraploidy in common clementine leaves was not associated with an increase in chloroplast numbers. This phenomenon appears to reduce photosynthetic capacity ${ }^{34}$. Overall, under optimal conditions and depending on the rootstock genotypes, the structural and/or ultrastructural modifications of common clementine leaves induced by rootstock tetraploidy could either compensate each other with no change in gas exchanges or induce a modification of gas exchanges. The number and size of transitory starch grains and mitochondria were either reduced or similar between $2 x$ and $4 x$ scion/rootstock combinations in palisade and spongy mesophylls (Tables 2 and 3; Fig. 2 and 3). The number of plastoglobuli increased in C/CM4x and C/CC4x compared to C/CM2x and C/CC2x in the chloroplasts of the palisade and spongy mesophylls. Only the $\mathrm{C} / \mathrm{CM} 4 \mathrm{x}$ plastoglobuli were larger than those of its $2 x$ counterpart (Tables 2 and 3; Fig. 2 and 3). Thus, rootstock tetraploidy involved a potential increase in lipid (plastoquinone-9 (PQ-9), plastoquinol-9 (PQ-9H2) and a-tocopherol (a-T)) reserves that could not be deposited in the thylakoids of chloroplasts.

Rootstock tetraploidy can induced modifications in the number and/or size of the investigated ultrastructural components.

\section{Differences in photosynthetic properties and redox status of scion/rootstock combinations under nutrient stress could be related to their leaf and cell anatomy}

Complete starvation resulted in a significant decrease in $\mathrm{N}$ but similar or higher levels of $\mathrm{P}, \mathrm{K}, \mathrm{Mg}, \mathrm{Ca}$ and $\mathrm{Na}$ than controls in all scion/rootstock combinations (Table 4). A concentration effect induced by the transfer of $\mathrm{N}$ to other tree areas could explain the increase in $\mathrm{P}, \mathrm{K}$ and $\mathrm{Mg}$ contents in all scion/rootstock combinations $^{35}$. Leaf chlorosis occurs when plants do not have the nutrients needed for chlorophyll synthesis, which in turn affects the photosynthetic efficiency ${ }^{36}$. However, the decrease in $\mathrm{N}$, which was an important factor in chlorosis, was similar in all scion/rootstock combinations (Table 4). C/CM4x showed less chlorosis as indicated by its light green colour compared with the yellow colour of other scion/rootstock combinations (Fig. 4). These results suggest a better integrity of chlorophyll content 
probably related to a better protection against $\operatorname{ROS}^{37-39}$. The improvements in the redox status of scions by tetraploid rootstocks is probably linked to an improvement in photosynthesis.

Chlorosis was associated with structural and ultrastructural foliar changes and a disruption of photosynthetic properties in all scion/rootstock combinations ${ }^{6,40}$ (Tables 1, 2 and 3; Fig. 5). At structural level, stomata and ostioles of all scion/rootstock combinations showed a narrowing which was associated with an increase in density (except in $\mathrm{C} / \mathrm{CC} 2 \mathrm{x}$ ) response to nutrient deficiency (Table 1; Fig. 1). The rootstock apparently has a different effect on the structural components of common clementine leaves depending on genotype and/or ploidy level. $P_{\text {net }}$ and $g_{\mathrm{s}}$ decreased concomitantly in all scion/rootstock combinations under nutrient deficiency (Fig. 5A-B). These results suggest a critical role of stomatal structure in the process of $\mathrm{CO}_{2}$ availability ${ }^{41}$. However, the smaller decrease in $P_{\text {net }}, g_{\mathrm{s}}$ and $F_{\mathrm{v}} / F_{\mathrm{m}}$ in $\mathrm{C} / \mathrm{CM} 4 \mathrm{x}$ than in other scion/rootstock combinations (Fig. 5) implies that other factors than stomata are needed to sustain photosynthesis ${ }^{42-44}$.

At ultrastructural level, nutrient deficiency resulted in cell size enlargement (except in C/CM2x spongy mesophyll), thylakoid with grana degradation and a decrease in chloroplast size in leaf mesophylls of all scion/rootstock combinations (Tables 2 and 3; Fig. 2 and 3). Similar results were recorded in other plants under conditions of high light stress, infection, dark-induced senescence or total nutrient deficiency ${ }^{6,20,45,46}$. Chloroplast degradation may be due to the significant decrease in $\mathrm{N}$ in the mature leaves of each scion/rootstock combination following the extensive remobilization of $\mathrm{N}$ present in the cell to younger leaves or storage areas during nutrient deficiency ${ }^{47,48}$ (Tables 2 and 3; Fig. 2 and 3).

The overproduction of reactive oxygen species (ROS) leads to alterations in the integrity of the membrane structures of cells, chloroplasts or thylakoids by a process called lipid peroxidation, one of the indicators of which is malondialdehyde (MDA). The lower MDA content in C/CM4x compared to other scion/rootstock combinations was consistent with the reduced damage to ultrastructure (Tables 2 and 3; Fig. 2, 3, and 6D). Thylakoid size and structure is dependent on the formation of PSII-LHCII supercomplexes ${ }^{49}$. In $\mathrm{C} / \mathrm{CM} 4 \mathrm{x}$, the lower decrease in $F_{\mathrm{v}} / F_{\mathrm{m}}$ suggests a more limited degradation of the PSII-LHCII supercomplexes reducing the disruption of electron transport for the photosynthetic reaction and thus the production of ROS ${ }^{50}$ (Fig. 5C and 6D). Maintaining the redox balance in C/CM4x decelerates the degradation of thylakoids resulting in a more efficient photosynthetic capacity $\left(P_{\text {net }}\right.$ and $\left.F_{\mathrm{v}} / F_{\mathrm{m}}\right)$ compared to C/CM2x, C/CC2x and C/CC4x after nutrient deficiency (Tables 2 and 3; Fig. 2, 3, 5A, 5C and 6D). Plastoglobuli are bound to thylakoids via their membranes. Studies have shown that plastoglobuli are involved in the formation and degradation of thylakoids during plant growth, development and senescence but also when plants are exposed to drought, high-light, $\mathrm{N}$ starvation or fungal infection ${ }^{46,51-}$ 53 . The reduced damage of the thylakoid membrane in $\mathrm{C} / \mathrm{CM} 4 \mathrm{x}$ would explain the maintenance of the plastoglobuli numbers and the small increase in their size due to the accumulation of catabolites formed by thylakoid degradation in their hydrophobic core compared to other scion/rootstock combinations ${ }^{54,55}$ (Tables 2 and 3; Fig. 2 and 3). 
Rootstock tetraploidy improves the tolerance of $2 x$ common clementine scions by maintaining the redox status and delaying ultrastructural changes and damage with a consequent improvement in photosynthetic capacity. However, as suggested by the similar impact of nutrient deficiency on C/CC2x and $\mathrm{C} / \mathrm{CC} 4 \mathrm{x}$, rootstock tetraploidy does not automatically result in better tolerance of the photosynthetic properties of the scion.

\section{Differences in tolerance to nutrient stress between scion/rootstock combinations may be explained by a better antioxidant system}

Nutrient deprivation led to a modification of oxidative metabolism ${ }^{35,39,56}$. Tolerance differences between scion/rootstock combinations may be related to differences in ROS production and/or antioxidant system efficiency. The enzymatic antioxidant system response differs according to plant species and the deficient minerals ${ }^{56-60}$. Enzymatic antioxidant systems in common clementine leaves differed depending on the rootstock genotypes (Fig. 6).

Nutrient deficiency impaired SOD activity in C/CC4x and C/CM4x (Fig. 6A). It was interesting to note that APX activity either increased or remained similar to the control in all scion/rootstock combinations (Fig. 6C) whereas CAT activity only increased in $\mathrm{C} / \mathrm{CM} 4 \mathrm{x}$ under nutrient deficiency (Fig. 6B). Concurrent CAT and $A P X$ activity is important for the elimination of $\mathrm{H}_{2} \mathrm{O}_{2}{ }^{61-63}$. In $\mathrm{C} / \mathrm{CM} 2 \mathrm{x}, \mathrm{C} / \mathrm{CC} 2 \mathrm{x}$ and $\mathrm{C} / \mathrm{CC} 4 \mathrm{x}$, the low $\mathrm{H}_{2} \mathrm{O}_{2}$ and high MDA contents were due to increased $\mathrm{OH}^{\circ}$ formation (Fig. $6 \mathrm{D}$ and $\mathrm{E}$ ). This $\mathrm{OH}^{\circ}$ is either directly formed by the addition of electrons to the $\mathrm{O}_{2}{ }^{--}$not transformed into $\mathrm{H}_{2} \mathrm{O}_{2}$ by SOD and/or by the transformation of $\mathrm{H}_{2} \mathrm{O}_{2}$ via Fenton or Haber-Weiss reactions when the APX activity is insufficient to compensate for the low CAT activity. Conversely, in C/CM4X, the synergistic activity of CAT and APX maintains the MDA content in $C / C M 4 x$ (Fig. $6 B, C$ and D).As in their ungrafted counterparts, the increased enzymatic activity may explain the reduced ultrastructural damage and decrease in photosynthetic activity in $\mathrm{C} / \mathrm{CM} 4 \mathrm{x}$ in comparison with the other scion/rootstock combinations. The improvement in performance of the enzyme-based antioxidant system in the scion is due to the tetraploidization of the rootstock and the compatibility between rootstock and scion.

In conclusion, rootstock ploidy level had no effect on the structure of the common clementine scion leaves (except stoma density in Carrizo citrange) whereas it induced modifications in the ultrastructural components. The impact of prolonged nutrient deficiency on the structure, ultrastructure, physiology and biochemistry of the common clementine scion differed according to the variety and ploidy level of the rootstock. Among the four scion/rootstock combinations, common clementine grafted with $4 \mathrm{x}$ citrumelo 4475 rootstock (C/CM4x) was the most tolerant to nutrient deficiency as indicated by the limited changes in leaf cell structures and photosynthetic activity. The improved tolerance of common clementine grafted with $4 x$ citrumelo 4475 rootstock may be related to a better antioxidant system. Tolerance to nutrient deficiency can therefore be improved by rootstock polyploidy but remains dependent on the rootstock 
genotype. The next step of this study will be to test the impact of rootstock ploidy level on the quality and yield of clementine fruit under nutrient deficiency.

\section{Materials And Methods}

\section{Plant material and experimental design}

The experiment was carried out on the AREFLEC experimental station located in San Giuliano, Corsica $\left(41^{\circ} 47^{\prime} 27^{\prime \prime} \mathrm{N}\right.$ and $\left.09^{\circ} 23^{\prime} 40^{\prime \prime} \mathrm{E}\right)$. 2x common clementine (Citrus clementina Hort. ex Tan; SRA 92) scion grafted onto one year seedlings of Carrizo citrange (Citrus sinensis L. Osb. $\times$ Poncirus trifoliata L. Raf.) and Citrumelo 4475 (Citrus paradisi L. Macf. $x$ Poncirus trifoliata L. Raf.) 2x (C/CC2x and C/CM2x, respectively) and their $4 x$ counterparts ( $/ C C 4 x$ and $C / C M 4 x$, respectively) were used as source materials. The ploidy status of six seedlings for each combination was first checked by flow 10 cytometry (Partec I, Germany) according to Froelicher et al. ${ }^{21}$. Clonal propagation by nucellar embryogenesis was checked by genotyping using SSR markers as described in Vieira et al. ${ }^{22}$.

The 24 selected scion/rootstock combinations were then grown under identical conditions in vermiculite with fertigation and water $(1 \mathrm{~L} / \mathrm{h})$ for three years in a tunnel greenhouse. The stock solution used for irrigation included: $20-5-10 \mathrm{NPK}+2 \mathrm{MgO}$ fertilizer + trace elements according to the recommendations of the French department of agriculture. Seedlings were divided into two blocks: one with reference fertigation (control plants) and the other with irrigation water (without nutrient inputs). A total of three plants of each scion/rootstock combination were randomized by fertigation level $(n=3)$. The fertigation solutions were prepared and applied with a metering pump. Before starting the experiment, the vermiculite was washed for 48 hours in order to eliminate any nutritional reserves in the pot.

According to a previous experiment of Oustric et al. ${ }^{20}$, leaf and root samples were collected and physiological measurements made from May to December 2018 at two different times (days): 0 (D0: control plant) and 210 (D210) days after the start of nutritional deprivation. Measurements were made and samples taken from homogeneous plants comprising four branches with fully-expanded leaves developed under stress and control conditions.

\section{Scanning electron microscopy (SEM)}

Scanning electron microscopy measurements were carried out on three leaf pieces per scion/rootstock combination and fertigation level (typically $\left.1 \mathrm{~cm}^{2}\right)(n=3)$ cut with a razor blade from mid-laminar areas at between 10:00 and 11:00 am. As described in Oustric et al. ${ }^{20}$, leaves were then immediately fixed in cold $\left(4^{\circ} \mathrm{C}\right) 2.5 \%(\mathrm{v} / \mathrm{v})$ glutaraldehyde in $0.1 \mathrm{M}$ sodium cacodylate buffer at $\mathrm{pH} 7.2$, rinsed in a $0.1 \mathrm{M}$ cacodylate buffer at $\mathrm{pH} 7.2$, dehydrated through a graded ethanol series (30\%, 50\%, 75\%, 90\% and 100\%) and dried under $\mathrm{CO}_{2}$ in an Emitech $\mathrm{K} 850$ critical point dryer (Quorum Technologies Ltd, Ashford, U.K.). Specimens were mounted on aluminum stubs with carbon double-sided adhesive disks, coated with 
gold/palladium in a SC7640 sputter coater (Quorum Technologies Ltd, Newhaven, U.K.) and examined under a S-3400N scanning electron microscope (Hitachi High-Technologies Corporation, Tokyo, Japan) at an accelerating voltage of $5 \mathrm{kV}$.

\section{Transmission electron microscopy (TEM)}

Transmission electron microscopy measurements were carried out on five leaf pieces per scion/rootstock combination and fertigation level (typically $\left.1 \mathrm{~mm}^{2}\right)(n=5)$ cut with a razor blade from mid-laminar areas at between 10:00 and 11:00 am. As described in Oustric et al. ${ }^{20}$, leaves were immediately fixed in cold (4 $\left.{ }^{\circ} \mathrm{C}\right) 2.5 \%$ glutaraldehyde in $0.1 \mathrm{M}$ sodium cacodylate buffer at $\mathrm{pH} 7.2$, rinsed in a $0.1 \mathrm{M}$ cacodylate buffer at $\mathrm{pH} 7.2$, post-fixed in cold $\left(4^{\circ} \mathrm{C}\right) 1 \%$ osmium tetroxide in the same buffer for $1 \mathrm{~h}$, dehydrated through a graded ethanol series (70\% and 100\%) and propylene oxide, embedded in Spurr, and polymerized at $60{ }^{\circ} \mathrm{C}$ for $24 \mathrm{~h}$. Ultra-thin sections (60-90 nm) were cut using a Power tome PC ultramicrotome (RMC Boeckeler, Tuscon, U.S.A.). Sections were placed on 200- and 300-mesh copper grids and stained with UranyLess (Delta Micoscopies, France) and lead citrate. They were then examined using a Hitachi H-7650 (Hitachi High-Technologies Corporation, Tokyo, Japan) at an accelerating voltage of $80 \mathrm{kV}$.

Mineral content was measured on a pool of eight fully expanded leaves for the three plants per combination and fertigation level $(n=3)$ between 10:00 and 11:00 am. Fresh leaves were placed in a forced air oven at $65 \pm 10^{\circ} \mathrm{C}$ overnight and then transferred into a desiccator for cooling. The dehydrated leaves were then sent to the CIRAD "Analyses des eaux, sols et végétaux service unit" at Montpellier (France) for analysis of macro- and micro-nutrients.

Leaf $\mathrm{P}, \mathrm{K}, \mathrm{Ca}, \mathrm{Mg}$ and $\mathrm{Na}$ contents were measured using an Agilent 720 simultaneous ICP-OES after double calcination with silica removal by adding hydrofluoric acid.

The leaf total $\mathrm{N}$ content was evaluated after combustion using a Leco TruMac $\mathrm{N}$ determinator.

\section{Measurements of gas exchange and chlorophyll a fluorescence}

All measurements were made on three fully developed leaves for each of the three plants per combination and fertigation level $(n=9)$. A portable photosynthesis system (LI600) was used to measure the leaf net photosynthetic rate $\left(P_{\text {net }}\right)$, stomatal conductance $\left(g_{\mathrm{s}}\right)$ and transpiration rate $(\mathrm{E})$ at between 7:00 and 11:00 am. The carbon dioxide concentration $\left(\mathrm{CO}_{2}\right)$, airflow rate, light intensity and temperature of the leaf chamber were maintained at $380 \mu \mathrm{mol} . \mathrm{mol}^{-1}, 500 \mu \mathrm{mol} . \mathrm{s}^{-1}, 1400 \mu \mathrm{mol} . \mathrm{m}^{-2} . \mathrm{s}^{-1}$ and $25^{\circ} \mathrm{C}$, respectively.

Chlorophyll a fluorescence parameters were measured using an 0S1p (Hansatech, Instruments Ltd) at between 9:00 and 11:00 am. Leaves were dark-acclimated for $30 \mathrm{~min}$ using special leaf clips. Chlorophyll a fluorescence was recorded after illumination with red actinic light $\left(650 \mathrm{~nm}, 3000 \mu \mathrm{mol}\right.$ photon. $\left.\mathrm{m}^{-2} \cdot \mathrm{s}^{-1}\right)$ 
for $1 \mathrm{~s}$ and this was used to calculate the maximum fluorescence $\left[F_{\mathrm{v}} / F_{\mathrm{m}}=\left(F_{\mathrm{m}}-F_{\mathrm{o}}\right) / \mathrm{F}_{\mathrm{m}}\right]^{23}$. Leaves were exposed to an actinic light to evaluate the current fluorescence yield $\left(F_{\mathrm{s}}\right)$ and the actual light-adapted fluorescence $\left(F_{\mathrm{m}}{ }^{\prime}\right)$. Formulas were applied to this data in order to determine the effective quantum yield of PSII Y $\left.(\mathrm{II})=\left(F_{\mathrm{m}}{ }^{\prime}-F_{\mathrm{s}}\right) / F_{\mathrm{m}}{ }^{\prime}\right]$, the $\left.\mathrm{Y}(\mathrm{NO})=F_{\mathrm{s}} / F_{\mathrm{m}}\right]$, the non-photochemical quenching coefficient $[\mathrm{Y}(\mathrm{NPQ})=$ $\left.\left(F_{\mathrm{s}} / F_{\mathrm{m}}{ }^{\prime}\right) \mathrm{Y}(\mathrm{NO})\right]^{24,25}$, and the electron transport rate through PSII [ETR(II) $\left.=\mathrm{Y}(\mathrm{II}) \times \mathrm{PAR} \times 0.5 \times 0.84\right]^{26}$. The $\mathrm{ETR} / P_{\text {net }}$ ratio was calculated to estimate the use of electrons in other processes unrelated to the photosynthetic $\mathrm{CO}_{2}$ assimilation rate.

\section{Determination of oxidative stress and antioxidant levels}

Biochemical analyses were performed on three samples for each scion/rootstock combination, i.e. one per tree, obtained by pooling eight fully-expanded leaves $(n=3)$ collected between 10:00 and 11:00 am and immediately immersed in liquid nitrogen and stored at $-80^{\circ} \mathrm{C}$. Immediately prior to biochemical analysis, each leaf and root sample was ground to a fine powder in liquid nitrogen.

Malondialdehyde (MDA) and antioxidant enzyme activities (SOD, CAT, and APX) were assayed as defined by Santini et al. ${ }^{27}$

Hydrogen peroxide $\left(\mathrm{H}_{2} \mathrm{O}_{2}\right)$ was assayed using the PeroxiDetect kit (Sigma-Aldrich). This technique is based on the oxidation of ferrous $\left(\mathrm{Fe}^{2+}\right)$ to ferric ions $\left(\mathrm{Fe}^{3+}\right)$ by hydroperoxides which react with xylenol orange ("3,3'-bis[N,N-bis(carboxymethyl)aminomethyl] o-cresolsulfonephthalein, sodium salt") to form a blue complex visible at $560 \mathrm{~nm}$.

Proline content was measured as described by Oustric et al. ${ }^{28}$

A V-630 spectrophotometer was used for all measurements (Jasco Inc., Tokyo, Japan).

\section{Statistical analyses}

All statistical measurements were performed with R statistical software (v.2.12.1) (http://www.Rproject.org) and the Rcmdr package. The qualitative factors studied were sampling date (D0 and D210 after nutrient deficiency), the comment clementine scion grafted onto rootstocks subjected to nutrient stress $(\mathrm{C} / \mathrm{CC}$ and $\mathrm{C} / \mathrm{CM})$ and the ploidy level of nutrient stressed rootstocks $(\mathrm{C} / \mathrm{CC} 2 \mathrm{x}, \mathrm{C} / \mathrm{CC} 4 \mathrm{x}, \mathrm{C} / \mathrm{CM} 2 \mathrm{x}$ and $\mathrm{C} / \mathrm{CM} 4 \mathrm{x}$ ). The influence of these three factors was analyzed using a two-way ANOVA followed by LSD test at $p<0.05$.

The microscopic data obtained on leaves of common clementine scion grafted onto the various rootstocks at D0 (control) and D210 of nutrient deficiency were analyzed by heatmaps generated by Heatmap.2 function of the gplot package 3.0.1 for Rstudio (v.1.3.1093) (https://rstudio.com). 


\section{Declarations}

\section{Acknowledgements}

This work was funded by the "Collectivité de Corse" as part of the "Innov'agrumes" research project (FEDER). We thank Jean-Claude Ribaut for hosting this study at the AREFLEC experimental station, and Gilles Paolacci and Paul Martin for installing and monitoring the fertigation system in the greenhouse.

\section{Author information}

Affiliations

Laboratoire Biochimie et Biologie Moléculaire du Végétal, CNRS, UMR 6134 SPE, Université de Corse, Corte, France

Julie Oustric, Jean Giannettini, Liliane Berti \& Jérémie Santini

UCA, INRA, PIAF, Clermont-Ferrand, France

Stéphane Herbette

Laboratoire Parasites et Ecosystèmes Méditerranéens", CNRS, UMR 6134 SPE, Université de Corse, Corte, France

Yann Quilichini

Equipe "Amélioration des Plantes à Multiplication Végétative", UMR AGAP, Département BIOS, CIRAD, Station de Roujol, Petit-Bourg, Guadeloupe

Raphael Morillon

\section{Contributions}

O.J. collected data, did the statistical analysis, interpreted the results and drafted the manuscript.

S.J. designed the study and drafted the manuscript.

Q.Y. participated collect microscopic data.

M.R., H.S., G.J. and B.L. designed the study and helped draft the manuscript.

\section{Ethics declarations}


Competing interests

The authors declare no competing interests.

\section{References}

1. Marschner, H. Mineral nutrition of higher plants 2 nd edition. Acad. G. B. (1995).

2. Grusak, M. A. Plant Macro-and Micronutrient Minerals. E LS(2001).

3. Lal, R. Enhancing crop yields in the developing countries through restoration of the soil organic carbon pool in agricultural lands. Land Degrad. Dev. 17, 197-209 (2006).

4. Ericsson, T. Growth and shoot: root ratio of seedlings in relation to nutrient availability. in Nutrient uptake and cycling in forest ecosystems 205-214 (Springer, 1995).

5. Kalaji, H. M. et al. Identification of nutrient deficiency in maize and tomato plants by in vivo chlorophyll a fluorescence measurements. Plant Physiol. Biochem. 81, 16-25 (2014).

6. Du, Q. et al. Effects of potassium deficiency on photosynthesis, chloroplast ultrastructure, ROS, and antioxidant activities in maize (Zea mays L.). J. Integr. Agric. 18, 395-406 (2019).

7. Mittler, R. Oxidative stress, antioxidants and stress tolerance. Trends Plant Sci. 7, 405-410 (2002).

8. Mittler, R., Vanderauwera, S., Gollery, M. \& Van Breusegem, F. Reactive oxygen gene network of plants. Trends Plant Sci. 9, 490-498 (2004).

9. Apel, K. \& Hirt, H. Reactive oxygen species: metabolism, oxidative stress, and signal transduction. Annu. Rev. Plant Biol. 55, 373-399 (2004).

10. Kucukyumuk, Z. \& Erdal, I. Rootstock and cultivar effect on mineral nutrition, seasonal nutrient variation and correlations among leaf, flower and fruit nutrient concentrations in apple trees. Bulg. J. Agric. Sci. 17, 633-641 (2011).

11. Martínez-Ballesta, M. C., Alcaraz-López, C., Muries, B., Mota-Cadenas, C. \& Carvajal, M. Physiological aspects of rootstock-scion interactions. Sci. Hortic. 127, 112-118 (2010).

12. Schwarz, D., Rouphael, Y., Colla, G. \& Venema, J. H. Grafting as a tool to improve tolerance of vegetables to abiotic stresses: Thermal stress, water stress and organic pollutants. Sci. Hortic. 127, 162-171 (2010).

13. Taylor, B. K. \& Dimsey, R. T. Rootstock and scion effects on the leaf nutrient composition of citrus trees. Aust. J. Exp. Agric. 33, 363-371 (1993).

14. Lu, Z.-J. et al. The effects of inarching Citrus reticulata Blanco var. tangerine on the tree vigor, nutrient status and fruit quality of Citrus sinensis Osbeck 'Newhall'trees that have Poncirus trifoliata (L.) Raf. as rootstocks. Sci. Hortic. 256, 108600 (2019).

15. Cameron, J. Genetics, breeding and nucellar embryony. Citrus Ind. 325-370 (1968).

16. Allario, T. et al. Tetraploid Rangpur lime rootstock increases drought tolerance via enhanced constitutive root abscisic acid production. vol. 36 (2013). 
17. Oustric, J. et al. Tetraploid Carrizo citrange rootstock (Citrus sinensis Osb. $\times$ Poncirus trifoliata L. Raf.) enhances natural chilling stress tolerance of common clementine (Citrus clementina Hort. Ex Tan J. Plant Physiol. 214, 108-115 (2017).

18. Balal, R. M. et al. Kinnow mandarin plants grafted on tetraploid rootstocks are more tolerant to $\mathrm{Cr}$ toxicity than those grafted on its diploids one. Environ. Exp. Bot. 140, 8-18 (2017).

19. Jacquemond, C., Curk, F. \& Heuzet, M. Les clémentiniers et autres petits agrumes. (Editions Quae, 2013).

20. Oustric, J. et al. Tetraploid citrus seedlings subjected to long-term nutrient deficiency are less affected at the ultrastructural, physiological and biochemical levels than diploid ones. Plant Physiol. Biochem. 135, 372-384 (2019).

21. Froelicher, Y. et al. Induced parthenogenesis in mandarin for haploid production: induction procedures and genetic analysis of plantlets. Plant Cell Rep. 26, 937-944 (2007).

22. Vieira, D. D. S. S. et al. Polyploidization alters constitutive content of volatile organic compounds (VOC) and improves membrane stability under water deficit in Volkamer lemon (Citrus limonia Osb.) leaves. Environ. Exp. Bot. 126, 1-9 (2016).

23. Maxwell, K. \& Johnson, G. N. Chlorophyll fluorescence-a practical guide. J. Exp. Bot. 51, 659-668 (2000).

24. Kramer, D. M., Johnson, G., Kiirats, O. \& Edwards, G. E. New fluorescence parameters for the determination of Q A redox state and excitation energy fluxes. Photosynth. Res. 79, 209 (2004).

25. Klughammer, C. \& Schreiber, U. Complementary PS II quantum yields calculated from simple fluorescence parameters measured by PAM fluorometry and the Saturation Pulse method. PAM Appl. Notes 1, 201-247 (2008).

26. Bilger, W., Schreiber, U. \& Bock, M. Determination of the quantum efficiency of photosystem II and of non-photochemical quenching of chlorophyll fluorescence in the field. Oecologia 102, 425-432 (1995).

27. Santini, J. et al. Comparison of photosynthesis and antioxidant performance of several Citrus and Fortunella species (Rutaceae) under natural chilling stress. Trees 27, 71-83 (2013).

28. Oustric, J. et al. Nutrient deficiency tolerance in citrus is dependent on genotype or ploidy level. Front. Plant Sci. 10, 127 (2019).

29. Padoan, D., Mossad, A., Chiancone, B., Germana, M. A. \& Khan, P. S. S. V. Ploidy levels in Citrus clementine affects leaf morphology, stomatal density and water content. Theor. Exp. Plant Physiol. 25, 283-290 (2013).

30. Jaskani, M. J., Khan, M. M. \& Khan, I. A. Growth, morphology and fruit comparison of diploid and tetraploid Kinnow mandarin. Pak. J. Agric. Sci. 39, 126-128 (2002).

31. Büssis, D., von Groll, U., Fisahn, J. \& Altmann, T. Stomatal aperture can compensate altered stomatal density in Arabidopsis thaliana at growth light conditions. Funct. Plant Biol. 33, 1037-1043 (2006). 
32. Sack, F. D. \& Paolillo Jr, D. J. Protoplasmic changes during stomatal development in Funaria. Can. J. Bot. 61, 2515-2526 (1983).

33. Horrer, D. et al. Blue light induces a distinct starch degradation pathway in guard cells for stomatal opening. Curr. Biol. 26, 362-370 (2016).

34. Okie, J. G., Smith, V. H. \& Martin-Cereceda, M. Major evolutionary transitions of life, metabolic scaling and the number and size of mitochondria and chloroplasts. Proc. R. Soc. B Biol. Sci. 283, 20160611 (2016).

35. Tewari, R. K., Kumar, P. \& Sharma, P. N. Oxidative stress and antioxidant responses in young leaves of mulberry plants grown under nitrogen, phosphorus or potassium deficiency. J. Integr. Plant Biol. 49, 313-322 (2007).

36. Sárvári, É. Effect of Cd on the iron re-supply-induced formation of chlorophyll-protein complexes in cucumber. Acta Biol. Szeged. 52, 183-186 (2008).

37. Shimshi, D. Leaf chlorosis and stomatal aperture. New Phytol. 66, 455-461 (1967).

38. Rodriguez de Cianzio, S., Fehr, de W. \& Anderson, I. C. Genotypic Evaluation for Iron Deficiency Chlorosis in Soybeans by Visual Scores and Chlorophyll Concentration 1. Crop Sci. 19, 644-646 (1979).

39. Cakmak, S., Gülüt, K. Y., Marschner, H. \& Graham, R. D. Effect of zinc and iron deficiency on phytos1 derophore release in wheat genotypes differing in zinc efficiency. J. Plant Nutr. 17, 1-17 (1994).

40. Wu, X., Lu, X., Riaz, M., Yan, L. \& Jiang, C. Boron toxicity induced specific changes of cell ultrastructure and architecture of components in leaf center and tip of trifoliate orange [Poncirus trifoliata (L.) Raf.]. J. Environ. Manage. 246, 426-433 (2019).

41. Flexas, J. et al. Diffusional conductances to $\mathrm{CO} 2$ as a target for increasing photosynthesis and photosynthetic water-use efficiency. Photosynth. Res. 117, 45-59 (2013).

42. Epron, D. \& Dreyer, E. Stomatal and non stomatal limitation of photosynthesis by leaf water deficits in three oak species: a comparison of gas exchange and chlorophyll a fluorescence data. Ann. Sci. For. 47, 435-450 (1990).

43. Flexas, J. \& Medrano, H. Drought-inhibition of Photosynthesis in C3 Plants: Stomatal and Nonstomatal Limitations Revisited. Ann. Bot. 89, 183-189 (2002).

44. Baker, N. R. Chlorophyll Fluorescence: A Probe of Photosynthesis In Vivo. Annu. Rev. Plant Biol. 59, 89-113 (2008).

45. Papadakis, I. E. et al. Mn-induced changes in leaf structure and chloroplast ultrastructure of Citrus volkameriana (L.) plants. J. Plant Physiol. 164, 100-103 (2007).

46. Zechmann, B. Subcellular Roles of Glutathione in Mediating Plant Defense during Biotic Stress. Plants 9, 1067 (2020).

47. Thomas, R. Q., Zaehle, S., Templer, P. H. \& Goodale, C. L. Global patterns of nitrogen limitation: confronting two global biogeochemical models with observations. Glob. Change Biol. 19, 2986- 
2998 (2013).

48. Pottier, M., Masclaux Daubresse, C., Yoshimoto, K. \& Thomine, S. Autophagy as a possible mechanism for micronutrient remobilization from leaves to seeds. Front. Plant Sci. 5, 11 (2014).

49. Kirchhoff, H. Diffusion of molecules and macromolecules in thylakoid membranes. Biochim. Biophys. Acta BBA-Bioenerg. 1837, 495-502 (2014).

50. Apel, K. \& Hirt, H. Reactive oxygen species: metabolism, oxidative stress, and signal transduction. Annu. Rev. Plant Biol. 55, 373-399 (2004).

51. Eymery, F. \& Rey, P. Immunocytolocalization of CDSP 32 and CDSP 34, two chloroplastic droughtinduced stress proteins in Solanum tuberosum plants. Plant Physiol. Biochem. 37, 305-312 (1999).

52. Zhang, M.-P. et al. Changes in chloroplast ultrastructure, fatty acid components of thylakoid membrane and chlorophyll a fluorescence transient in flag leaves of a super-high-yield hybrid rice and its parents during the reproductive stage. J. Plant Physiol. 167, 277-285 (2010).

53. Fatihi, A. et al. A dedicated type II NADPH dehydrogenase performs the penultimate step in the biosynthesis of vitamin K1 in Synechocystis and Arabidopsis. Plant Cell 27, 1730-1741 (2015).

54. Spiller, S. \& Terry, N. Limiting factors in photosynthesis. II. Iron stress diminishes photochemical capacity by reducing the number of photosynthetic units. Plant Physiol. 65, 121-5 (1980).

55. Besagni, C. \& Kessler, F. A mechanism implicating plastoglobules in thylakoid disassembly during senescence and nitrogen starvation. Planta 237, 463-470 (2013).

56. Huang, S. et al. Improving nutritional quality of maize proteins by expressing sense and antisense zein genes. J. Agric. Food Chem. 52, 1958-1964 (2004).

57. Del Rio, L. A., Gomez, M., Yanez, J., Leal, A. \& Gorge, J. L. Iron deficiency in pea plants effect on catalase, peroxidase, chlorophyll and proteins of leaves. Plant Soil 49, 343-353 (1978).

58. Tewari, R. K. Role of mineral nutrient elements in Mulberry (Morus alba L.) Plants with particular reference to oxidative metabolism. (Ph. D thesis, University of Lucknow, INDIA, 2004).

59. Gorbe, E. \& Calatayud, Á. Optimization of Nutrition in Soilless Systems: A Review. in Advances in Botanical Research (eds. Kader, J.-C. \& Delseny, M.) vol. 53 193-245 (Academic Press, 2010).

60. Valipour, M., Baninasab, B., Khoshgoftarmanesh, A. H. \& Gholami, M. Oxidative stress and antioxidant responses to direct and bicarbonate-induced iron deficiency in two quince rootstocks. Sci. Hortic. 261, 108933 (2020).

61. Hertwig, B., Streb, P. \& Feierabend, J. Light dependence of catalase synthesis and degradation in leaves and the influence of interfering stress conditions. Plant Physiol. 100, 1547-1553 (1992).

62. Wang, J., Zhang, H. \& Allen, R. D. Overexpression of an Arabidopsis Peroxisomal Ascorbate Peroxidase Gene in Tobacco Increases Protection Against Oxidative Stress. Plant Cell Physiol. 40, 725-732 (1999).

63. Shigeoka, S. et al. Regulation and function of ascorbate peroxidase isoenzymes. J. Exp. Bot. 53, 1305-1319 (2002). 


\section{Tables}

Due to technical limitations, all tables are only available as a download in the Supplemental Files section. 